Elżbieta Kornalska

Andrzej Krasnodębski

Janusz Żmija

Witold Trela

\title{
3.2. EFFECT OF EUROPEAN FUNDS ON THE DEVELOPMENT OF AGRICULTURAL FARMS IN POLAND
}

\begin{abstract}
Summary
The paper strives to present the level of diversification of agricultural development in Poland resulting from the uneven utilization of European funds allocated to this aim. Development of agriculture is determined significantly by the scale of investment in this sector. Therefore, this article analyses the measure "Modernization of agricultural farms" of RDP 2007-2013 and the state of the utilization of its measures by agricultural farms in the individual regions of Poland. The degree of activity and efficiency of beneficiaries in acquisition of European funds were determined in the paper and an attempt was made at identification of factors diversifying it.
\end{abstract}

Keywords: RDP 2007-2013, European funds, agricultural farm

\section{Introduction}

Agriculture is a special sector, standing out among other sections of national economy. It is due to the fact that production in this sector is based on living animals and undergoes their biorythms. It is also characterized by long cycles of production and seasonality. Capital turnover is much slower than in the other sectors of economy. Moreover, agriculture fulfills not only an important social and biological, but also a feeding function. Ensuring food security, which became crucially important after the experiences of the Second World War, inclined 6 countries: Federal Republic of Germany, Italy, France, Luxembourg, Belgium and the Netherlands to form the European Economic Community in 1957. Specificity of agriculture was acknowledged by the treaty founding the organization and known as the Treaty of Rome, which recognized "the particular nature of agricultural activity, which results from the economic and social structure of agriculture and from structural and natural disparities and different production structures between various agricultural regions".

In practice it led to subjecting food economy to the state protectionism.

The objectives specified in article 39 of the Treaty of Rome were to contribute to:

a) increase in agricultural productivity by promoting technical progress and the more efficient utilisation of the factors of production,

b) increase in farmers' incomes, ensuring a fair standard of living for the agricultural community,

c) stabilisation of agricultural markets;

d) ensuring the continuous availability of supplies to people;

e) ensuring the reasonable prices for consumers. 
The first plans and premises of establishing a common market, agricultural union or "green pool" in Western Europe appeared in the fifties of the $20^{\text {th }}$ century. At that time, the ministers of agriculture of the Netherlands - S.L.Mansholt and France - P. Pflimlin at the conference in Stresa, Italy, addressesd the issue of formulating the principles of agricultural policy, which have been in force until this day. These comprise: the market unity, Community (European) preference and financial solidarity.

Common Agricultural Policy is the oldest EU policy, yet it comprises the greatest number of regulations. It was launched to protect the agriculture of Western Europe, destroyed during the war. It was meant as a protective mesure against market fluctuations and ensure a constant growth of agricultural production experiencing food deficiency in Europe. Common Agricultural Policy was first implemented on 14 January, 1962 by signing the Brussels agreements. At that time the crucial decisions were made concerning the method of functioning of the Common Organisation of the Market in Cereals (Musiał and Legutko, 2000).

The legal foundation of CAP financing is Art. 40, paragraph 4 of the Treaty of Rome, which assumes that one or several agricultural guidance and guarantee funds may be set up. Finally, in 1962 the European Agricultural Guidance and Guarantee Fund was set up by Regulation No 25 of 1962 of the Council. A duality of the common agricultural policy comprising the market policy and structural policy rendered necessary separation two sections within the Fund: Guidance and Orientation. (Czapla and Guba, 2002)

Guarantee Section financed common agricultural policy; Orientation Section was the source of funding for structural transformations of agriculture and multifunctional rural development. For over 45 years of common agricultural policy implementation, the objectives stated in the Treaty of Rome have not been changed. The support instruments have been changed, since additional objectives supporting structural transformations of agriculture have been determined.

Common Agricultural Policy was successful enough to allow for a fast satisfying the demand for agricultural products and then led to an overproduction phenomenon. The costs of CAP were growing dramatically and during the peak period exceeded $70 \%$ of the EU budget. Many experts criticised export subsidies applied in the EU for their negative effect on economic cooperation with other countries. Liberalisation of food trade led to a gradual decrease in these subsidies. Despite a considerable gradual reduction, expenses on agriculture still account for c.a. $45 \%$ of the European Union budget, whereas the phenomenon of surplus production remains a serious problem and must be restrained by a complicated and costly system of regulations. Therefore, subsequent regulations were introduced in the nineties of the $20^{\text {th }}$ century, which were to stop constantly growing overproduction and decrease the prices of agricultural products, at the same time avoiding a decline in farmers' incomes. The directions of changes of agricultural policy were a response to changing external (criticism of GATT, later WTO) and internal (criticism of consumers an tax payers) conditions.

Summing up: Common Agricultural Policy, which is a common, transnational agricultural policy comprising the membership in a common open market but also the unity of European interests and financial solidarity, has undergone evolutionary 
development and subsequent reforms. It has been shaped also under the influence of actual crisis situations and has become increasingly more dependant on difficult, changing environmental and climatic conditions. The changes resulted also from the subsequent EU extensions which caused a deepening disparities in agriculture due to the natural conditions, structure and size of farms and structure of production. Despite the above mentioned facts, Common Agricultural Policy does not solve all problems, since it addresses the entities of various size and scale of activities (farm with large production potential but also small subsistence farms). Small farms prevail in many countries and regions in Europe, or at least they are significant for the agrarian structure. They constitute an important entity of agricultural economy, engaging a considerable human potential and capital. They function in all European Union states. Their activities encounter similar problems as faced by large commercial farms. Due to small scale of production and low incomes, small farms usually are unable to meet the challenges posed by globalisation of food turnover, growing competition or increasing requirements of the community pertaining to a widely understood natural environment protection.

Poland is a specific example of a developed country where a large number of so called small "family" farms remained, in which subsistence farms, allocating up to a half of their entire product to their own needs, account for as much as $2 / 5$ of the total number. (Zegar, 2012) Among the other farms almost 2/3 are semi-subsistence farms.A considerable group of these farms are developing relatively fast, adjusting to the market principles and uses the EU Common Agricultural Policy instruments. However, small farms, which constitute a majority, wrestle with a problem of effective utilisation of their resource and are unprofitable. They are mainly grouped in the southeastern and central regions of Poland. Their flexibility and adjustment to the market requirements progress slowly, however the farms more and more frequently apply for and use the European Union funds affording them a quicker adjustment to the market and becoming competitive. Small family farms are usually associated with a relatively small scale of production, great biodiversity, modern technologies, ecological equilibrium and environmental quality, as well as with high quality of manufactured products targeting selected groups of consumers and preserving rural cultural heritage.

However, there is still no clearly defined borderline between a family farm, small and big farm. There are also several definitions of "agricultural farm" functioning in Polish subject literature and in practice. However, as the most common is considered the definition used for statistical purposes, which states that: an agricultural farm denotes ploughlands with forest lands, buildings or their parts, equipment and livestock, if they constitute or may constitute organized economic entity and laws connected with running an agricultural farm.

According to the results of Agricultural census 2010 (in: Charakterystyka gospodarstw rolnych. Powszechny Spis Rolny, 2012), in June 2010 the number of agricultural farms in Poland was 2280 thousand (of which 1892 thousand farms were 
conducting agricultural activities, whereas in 2011 the number of farms decreased to 1583 thousand). Of this number almost $100 \%$ of farms belonged to private sector ${ }^{1}$.

Figure 1 shows the position of Poland among selected European Union countries, in which the number of agricultural farms exceeded 300 thousands.

Figure 1: Agricultural farms conducting agricultural activities in 2010 in the European Union countries

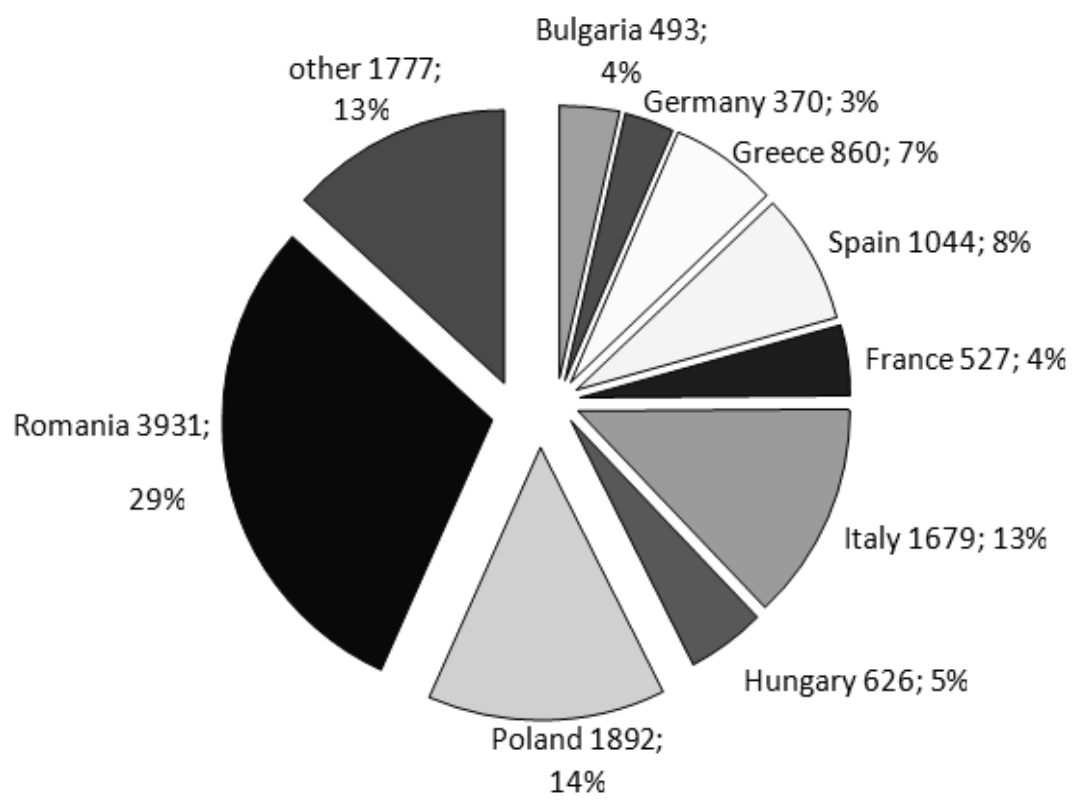

Source: SAEPR FAPA based on EUROSTAT (2011)

Average farm area in Poland is 10.1 ha whereas an average economic size of a farm in Poland is 3.6 ESU (at EU average -11.3 ESU). For comparison, an average economic size in Slovakia is 7 ESU, while in France 54 ESU.

\section{Material and methods}

Presented article strives to evidence the level of diversification of agriculture in Poland resulting from unequal utilization of European funds allocated to this purpose. The empirical material constituted of statistical data originating from EUROSTAT, GUS and the Agency for Restructuring and Modernisation of Agriculture (ARMA) reffering to RDP 2007-2013 measure "Modernisation of agricultural farms (MAF)".

Descriptive and comparative analysis, and cause-and effect analyis were the methods applied in the paper, whereas the results were presented graphically.

\footnotetext{
${ }^{1}$ Agricultural Census 2012 was conducted eight years after the previous analogous census. The census is particularly interesting and decisive, since it had place after Poland's integration into the European Union. Collected data is crucially important for many organs of both state administration and institutional structure of EU, OECD and FAO.
} 


\section{Description of the programme}

In 2007, a new financial perspective spanning the years 2007-2013 (RDP 20072013) was launched in the European Union member states. Its main objective is realisation of the concept of multifunctionality of agriculture and rural areas, and economic strenghtening of agricultural farms (Kornalska and Treka, 2012). At the same time it aims at ensuring the instruments to diversify economic acivities towards creating alternative sources of income and improving the quality of life in rural areas. (Rowiński , 2004)

RDP 2007-2013 (Rural Development programme) is composed of 4 axes:

- Axis 1 (Economic) : Improvement of the competitiveness of the agricultural and forestry sector

- Axis 2 (Environmental): Improving the environment and the countryside

- Axis 3 (Social) : Improvement of the quality of life in rural areas and diversification of rural economy

- Axis 4: LEADER.

The measures planned under Axis 1 and Axis 3, among these: Modernisation of agricultural farms and Diversification into non-agricultural activities, are still the most popular among farmers - beneficiaries, which has been reflected in the structure of RDP budget.

Initiating the Modernisation of agricultural farms (MAF) measure was determined by the fact that agricultural farms in the Republic of Poland are in the process of adjustment to the functioning on the European Union Common Market. There is a great need for the financial support of the investments targeting the improvement of the competitiveness of agricultural farms through modernisation of technical infrastructure of production, adapting the profile, scale and quality of production to market needs, improvement of food safety, improvement of animal welfare, natural environment protection or work safety.

The objective of the measure is supporting modernisation of farms to increase their efficiency through better utilisation of agronomic inputs, including introduction of new technologies of production, improvement of production quality, diversification of agricultural activities, but also harmonisation of conditions of production with the requirements of the natural environment protection, hygiene of production and animal welfare. The aim of the measure is also ensuring the agricultural producers running dairy production a possibility to adjust to changing conditions due to the planned termination of milk quota system in 2015. Under the framework of MAF the support will be provided for investments in modernisation or development of the primary crop or livestock production, excluding production related to forestry and fisheries. The operations may concern manufacturing of both food and non-food products (including agricultural products used for renewable energy generation), but also preparation of agricultural products produced on farm for wholesale or direct sale. The activities may also comprise investments on generating and utilisation of renewable energy for the needs of agricultural production.

The aid will be granted for the investments which will not cause an increase in production for which there is no market. 
Financial assistance may be provided for the investments on farm adjustment to the standards resulting from the European Union legislation:

1. Provisions in force - provided that the investment is made by a beneficiary of the measure "Setting-up of young farmers" according to a business plan, whereas the farm adjustment will be accomplished before 36 months from the start up of running the agricultural farm;

2. Newly introduced provisions - provided that the adjustment will be accomplished during the period of no longer than 36 months from the day when the standard came into force.

According to the main objective of the measure, the aid is granted for the investment which:

1. will contribute to improvement of total results of the farm:

a) increase in gross added value (GVA) on farm, particularly in result of rationalisation of technology of production or introducing innovation, change of profile or scale of production, improvement of the quality of production or increasing product added value, or

b) improvement of the situation on farm pertaining to protection of the natural environment, or

c) improvement of the situation on farm concerning animal welfare, or

d) improvement of the situation on farm concerning the hygiene and safety of production, or

e) improvement of the situation on farm concerning road infrastructure,

2. satisfies the requirements stated by the law regulations;

3. has been justified as to the amount of expenditure;

4. is not of an investment replacement character.

The beneficiaries must fulfill the following conditions:

- European Size Unit (ESU) - the farm where the investment is made is economically viable (the farm economic size equals at least 4 ESU) and is run by a person possessing adequate professional qualifications (where justified the qualifications may be completed during the so called transitional period).

- Both tangible and intangible investments on modernisation of agricural production are supported by MAF, in particular:

1. Tangible investments:

a) construction or renovation involving modernisation of buidings or houses,

b) purchase or installation of machinery or equipment, including computers,

c) setting up, modernisation of orchards or perennial plantations,

d) purchase, installation or construction of the elements of technical infrastructure directly affecting the conditions of conducting agricultural activity, preparation for sale or direct sale;

2. Intangible investments:

a) purchase of patents, licenses, including software licenses,

b) services connected with preparation of technical or economic documentation concerning the project and techical supervision, directly connected with the project realization. 
In most of the farms in Poland, both the amount and quality of equipment necessary for agricultural production are insufficient, therefore modernisation of farm technical facilities is necessary. Because of high costs of major equipment and relatively low incomes generated by agricultural activity in Poland, it is permissible to purchase second hand equipment, but no older than 5 years.

Leasing of machines or appliances is also permissible. The programme beneficiary may be a physical person, legal person or partnership running agricultural activities in the field of crop or livestock production. The physical person must be of age but below the retirement age.

The financial support under this measure may granted for investments adjusting the farm to the Community standards which have been in force for less than 36 months. The investments may involve adjustment to the standards resulting from the implementation of directive $91 / 676 /$ EWG on water protection against pollution caused by nitrates from agriculture:

- adaptation of farms to the standards stated in programmes aiming at reduction of nitrogen outflow from agricultural sources in the appointed, particularly threatened areas (PTA).

- Programmes of activities targeting individual PTAs, on the basis of local legal acts (decree of the director of general or regional directorate of water management) have been launched since 2004 and span 4-year periods. These programmes comprise among others farm adjustment concerning storage of natural fertilizers and bulk animal feeds.

- The support under Modernisation of agricultural farms (MAF) measure may be also granted for investments adapting the farms owned by the beneficiaries of "Setting up of young farmers" scheme, included in RDP 2007-2013, to the community standards in the areas of hygiene of production and animal welfare.

The aid is granted in the form of reimbursement of the eligible costs (parts of costs incurred by investment realisation).

The maximum amount of financial aid granted for one beneficiary per one farm under the measure, during the period of RDP realisation cannot exceed 300000 PLZ (76 848.2 EUR). The amount in euro is indicative. (Zieliński and Żmija, 2012)

The operations which eligible costs exceed 20 thousands PLZ, will be accepted for funding. The limit does not apply to the activities comprising exclusively agricultural farm equipment in appliances for natural fertilizer storage or projects connected with adjustment to the Community standards (Dokument rządowy PROW 2007-2013, 2012).

\section{Aid intensity under the programme framework}

The level of aid is a maximum of:

- $40 \%$ of the costs of investment eligible for financial aid;

- $50 \%$ of the costs of investment eligible for financial aid realized by a physical person who was under 40 years old on the day of application submission;

- $50 \%$ of the costs of investment eligible for financial aid, realized in the mountain areas, other less favoured areas, in agricultural areas within the NATURA 2000 
network or in the areas where restrictions associated with the Framework Water Directive implementation apply;

- $60 \%$ of the costs of investment eligible for financial aid realized by a physical person who was under 40 years old on the day of application submission, in the mountain areas, other less favoured areas, in agricultural areas within the NATURA 2000 network or in the areas where restrictions associated with the Framework Water Directive implementation apply;

- $75 \%$ of the costs of investment eligible for financial aid realized because of the enactment of Nitrate Directive - applies to the contracts signed before 30 April, 2008.

Financial aid granted under the "Modernisation of agricultural farms" measure may partially overlap the aid granted under the same measure, implemented in the framework of the National Restructuring Programme.

In order to eliminate a double financing of the same operations from two different sources, administrative checks will be carried out by the Agency for Restructuring and Modernisation of Agriculture and Agricultural Market Agency.

Table 1: Quantified target values for joint monitoring indicators

\begin{tabular}{|c|c|c|}
\hline $\begin{array}{c}\text { Indicator } \\
\text { type }\end{array}$ & Indicator & $\begin{array}{l}\text { Target value } \\
2007-2013\end{array}$ \\
\hline \multirow{2}{*}{ Product } & $\begin{array}{l}\text { Number of agricultural farms which obtained aid } \\
\text { (also under "new challenges" scheme) }\end{array}$ & $\begin{array}{l}63214 \\
(1588)\end{array}$ \\
\hline & $\begin{array}{l}\text { Total value of investments (EUR) } \\
\text { (also under "new challenges" scheme) }\end{array}$ & $\begin{array}{l}4796890923 \\
(172840278)\end{array}$ \\
\hline \multirow{2}{*}{ Outcome } & $\begin{array}{l}\text { Number of farms, which introduced new products } \\
\text { and/or technologies } \\
\text { (also under "new challenges" scheme) }\end{array}$ & $\begin{array}{l}47404 \\
(1 \quad 183)\end{array}$ \\
\hline & $\begin{array}{l}\text { Increase in gross added value on farms which } \\
\text { obtained aid (in EUR) } \\
\text { (also under "new challenges" scheme) }\end{array}$ & $\begin{array}{l}1330000000 \\
(48358284)\end{array}$ \\
\hline \multirow[b]{2}{*}{ Effect } & Economic growth & $\begin{array}{l}\text { Growth by } 50.1 \% \\
\text { (including } 0.41 \% \text { from RDP) }\end{array}$ \\
\hline & Labour productivity & $\begin{array}{c}\text { Growth by } 47.8 \% \\
\text { (including } 0.49 \% \text { from RDP) } \\
\text { Target value } \\
22270 \text { EUR per person }\end{array}$ \\
\hline
\end{tabular}

Source: RDP 2007-2013, state document based on Dokument rządowy PROW 2007-2013 (2012)

The list above shows the indicators used by the Agency for Restructuring and Modernisation of Agriculture for monitoring of the implementation and realization of the Modernisation of Agricultural Farms measure. At the same time they indicate the main financial-economic assuptions of the measure. 


\section{Discussion}

Since its transition to the free market economy system, Poland has been making up for the losses due to economic banckwardness and previous lack of democracy, among others through realisation of strategy of development and the European Union policy. It has been evident in the first place in industries, transport, infrastructure, agriculture or protection of the environment. It should be emphasized, that the changes connected with the system transformation after 1989 are positively perceived by a majority of citizens. However, some of the changes still involve a number of distressing phenomena, such as a necessity to adjust to changing cultural or social circumstances. It is particularly difficult for the oldest age groups but also for rural communities.

Since 1994, when Poland made effort for its membership in the European Communities, Polish agriculture has been in the first place covered by the adjustment schemes to satisfy the integration requirements, and next by the activities aimed at improving the competitiveness of agricultural farms.

Accession of Poland to the European Union in 2004 completed the pre-accession period, whereas it raised hopes and evoked considerable interest among Polish farmers in financial assistance which became available from the EU funds. At the same time, potential beneficiaries became apprehensive, reluctant and lost in a multitude of measures offered by individual assistance programmes. The most common barriers were legal procedures and also legislative problems. A serious problem in Poland is the specificity of Polish agriculture and rural areas, particularly considerable land parcelling and accompanying agrarian overpopulation. Therefore, rural development became a priority in Poland (Drygas, 2008). It has been a complicated process involving many entities, whereas the problems which must be solved are usually complex and have been established for many decades. In Poland it refers to $93 \%$ of the country area and concerns almost $15 \mathrm{M}$ people, which is $39 \%$ of the country population.

Poland, as a not very rich country, where rural areas cover such a large part of the territory and their inhabitants make up a considerable proportion of the citizens, cannot afford ignoring the problems of agriculture, non-utilisation or low efficiency of possessed resources utilisation. Therefore, recognition of Polish agriculture potential, the ways of its more effective utilisation and analysis of necessary adjustments seems important. (Klepacki, 2003)

Agriculture in Poland is of greater social and economic significance than in the other EU member states. However, it does not mean that the condition of agricultural sector is on a high level. According to EUROSTAT data published in 2007, six Polish voivodships, where agriculture share in national economy is considerable in relation to the other sectors, are among the poorest regions of the European Union.

Currently prevailing opinion among farmers is that not only large area farms are viable, but also smaller ones possessing below 50 ha, on condition they will "hit on an idea for business" and will manage their resources more cost-effectively.

As results from Agribus research, conducted by Martin \& Jacob Agency (Badanie Agribus 2012), investment outlays in agriculture and hunting increase every year (Figure 2). 
Kornalska, E. - Krasnodębski, A. - Żmija, J. - Trela, W.

Figure 2: Investment outlays (in billion PLZ) in agriculture and hunting

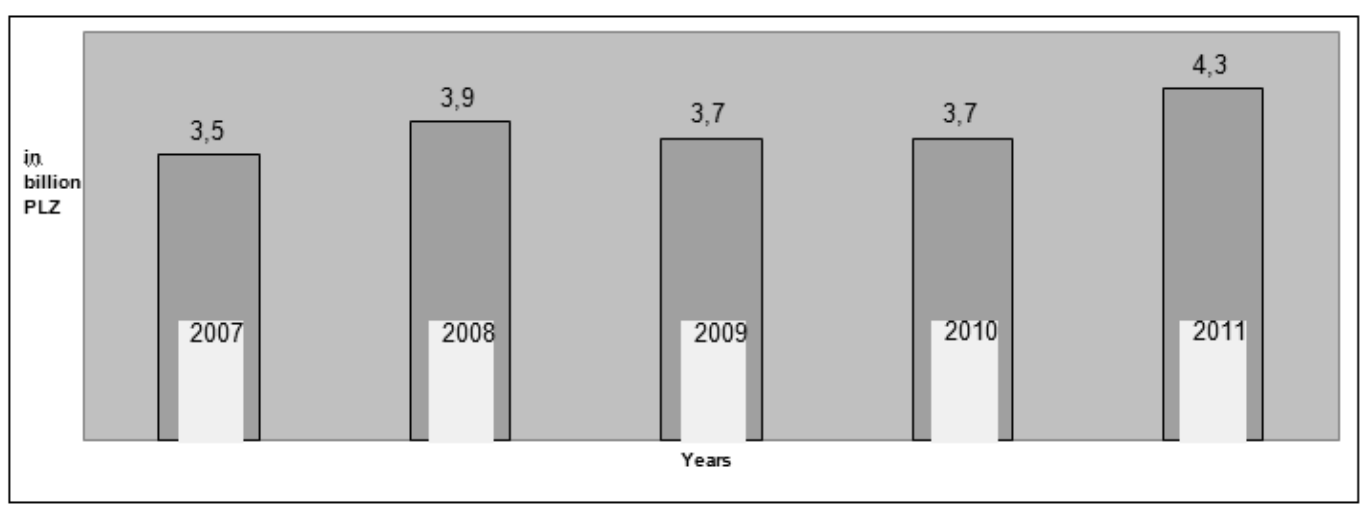

Source: Agribus research, 2012, Martin \&Jacob Agency

The data above are coherent with the data supplied by GUS, according to which modernisation, construction of farm buildings, machinery, appliances and tools occupy dominant position among the investments, reaching 1.6 billion zlotys. In 2012 farms purchased 19.3 thousand tractors (11 percent more than in 2010). It is also reflected in financial situation of farmers.

Data of the Main Statistical Office (GUS) reveal that expenses on maintenance and running of agricultural farm constitute $56 \%$ of the household expenditure $(34 \%$ are living expenses, $10 \%$ expenses for luxury goods). All investments in farms have been equally co-financed from the European Union funds.

Table 2: Number of submitted applications, signed contracts and their values within the MAF measure in the years 2007, 2009 and 2011

\begin{tabular}{|c|c|c|}
\hline Year & Category & Country/Poland \\
\hline \multirow{3}{*}{2007} & Submitted applications & 18372 \\
\hline & Signed contracts & 14335 \\
\hline & Amount (PLN) & 1820226280,97 \\
\hline \multirow{3}{*}{2009} & Submitted applications & 24863 \\
\hline & Signed contracts & 20327 \\
\hline & Amount (PLN) & 2968667653,88 \\
\hline \multirow{3}{*}{2011} & Submitted applications & 34676 \\
\hline & Signed contracts & ongoing \\
\hline & Requested amount (PLN) & 5149900534,18 \\
\hline
\end{tabular}

Source: Author's own studies based on ARMA data (Dokument rządowy PROW 2007-2013, 2012)

Modernisation of buildings and purchase of machines are among the main tasks financed under the Modernisation of Agricultural Farms measure. The measure is a part of RDP 2007-2013, Axis 1 (Economic) - Improving the competitiveness of the agricultural and forestry sector. A farmer, the beneficiary using assistance under the 
MAF measure may obtain financial assistance to the amount not exceeding 600 thousands zlotys (in which 50\% is his own input and 50\% the EU funds).

There were three rounds of fund allocation under MAF measure in Poland, respectively in 2007, 2009 and 2011.

Each successive opportunity of application for external funds aimed at supporting investments in farms brought a definite increase in the number of applications (see at Table 2.). Due to formal reasons (for example missing information or incorrectly filled applications), many of the submitted applications were not taken into consideration, yet it did not prevent further applications for funds.

Figure 3 shows activeness of agricultural farms in individual regions of Poland. The second call for proposals indicates a considerable increase in the activeness. This group comprised not only new beneficiaries but also the farmers who have not used the maximum amount of allocated funds.

Figure 3: Call for proposals under MAF measure per regions

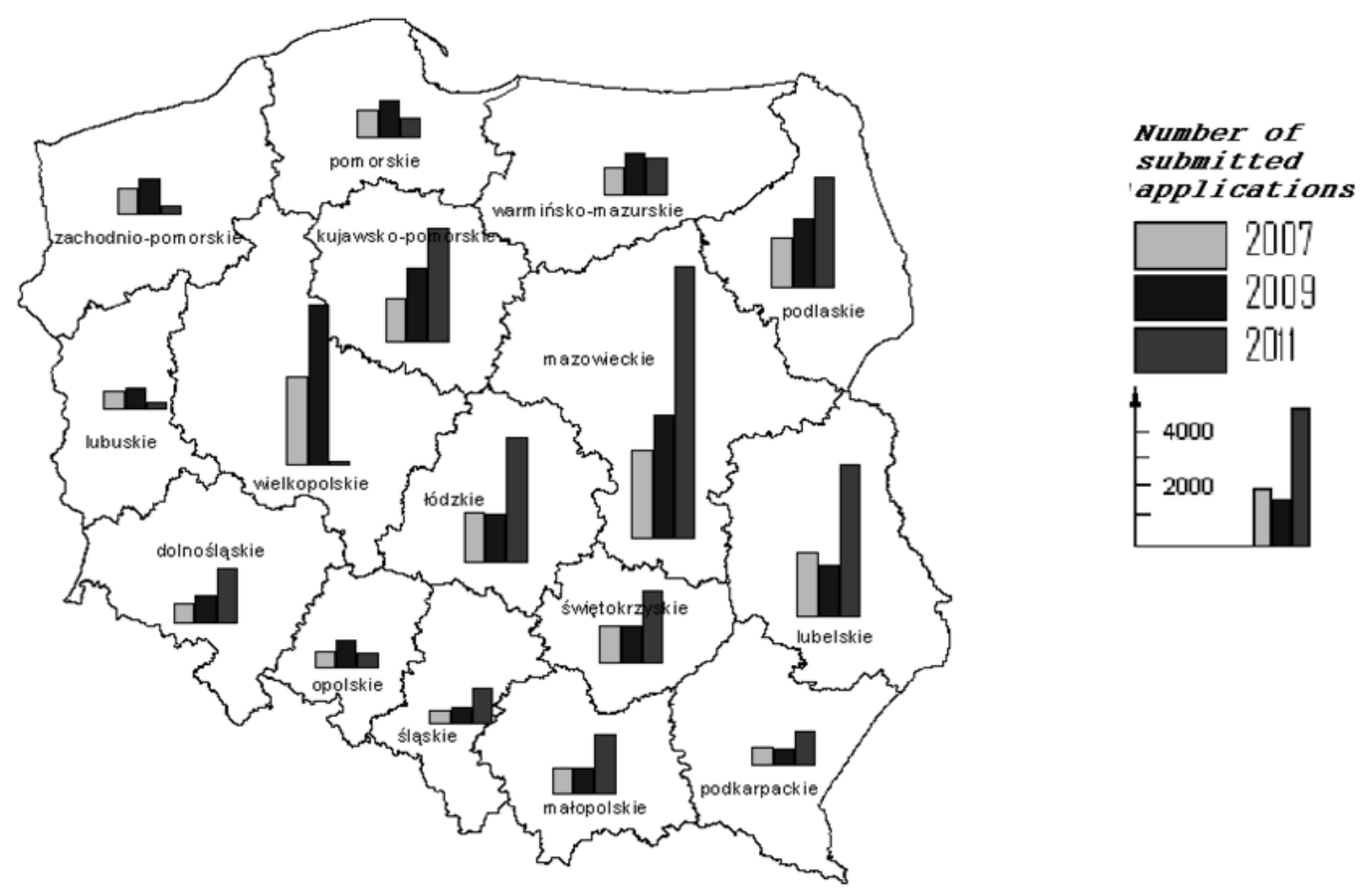

Source: Authors' own studies on the basis of ARMA data (2012)

Table 3 shows indicative degree of funds utilisation per one rural inhabitant, per one farm and per 1 ha AL. Despite considerable activeness of farmers, the data presented above are not satisfactory. In comparison with other European countries Poland occupies a far place in the ranking of countries - beneficiaries of Rural Development Programme. (Szumski, 2007) 
Kornalska, E. - Krasnodębski, A. - Żmija, J. - Trela, W.

Table 3: Utilization of funds allocated to MAF in Poland (as of 31.12.2011)

\begin{tabular}{|l|r|}
\hline \multicolumn{1}{|c|}{ Utilization of funds within the Framework of RDP } & \multicolumn{1}{|c|}{ Poland } \\
\hline Total [zł] & 4182230915.06 \\
Total [€] ass. $1 €=4,00 \mathrm{zł}$ & 1045557728.76 \\
\hline Per one rural inhabitant [zł] & 411.24 \\
Per one rural inhabitant [€] & 102.81 \\
\hline Per farm [zł] & 2641.96 \\
Per farm [€] & 660.49 \\
\hline Per 1 ha AL [zł] & 258.53 \\
Per 1 ha AL [€] & 64.63 \\
\hline
\end{tabular}

Note: assuming $1 €=4,00 \mathrm{zl}$

Source: Authors' own studies based on ARMA 2012 (ARiMR , 2012)

The ratio of the amount of granted assistance to the number of farms (as stated by GUS) and the number of entities registered in the register of producers kept by ARMA shows that: Zachodniopomorskie, Warmińsko-Mazurskie, Pomorskie, KujawskoPomorskie, Lubuskie and Wielkopolskie voivodships reached the highest indicators (Figure 4). These voivodships are the largest ones considering the farm area and number of agricultural farms.

Figure 4: Amount of assistance co-financed from the EU, allocated by ARMA in 20022011 per agricultural farm and entity registered in the Producers' Register (31.10.2011.)

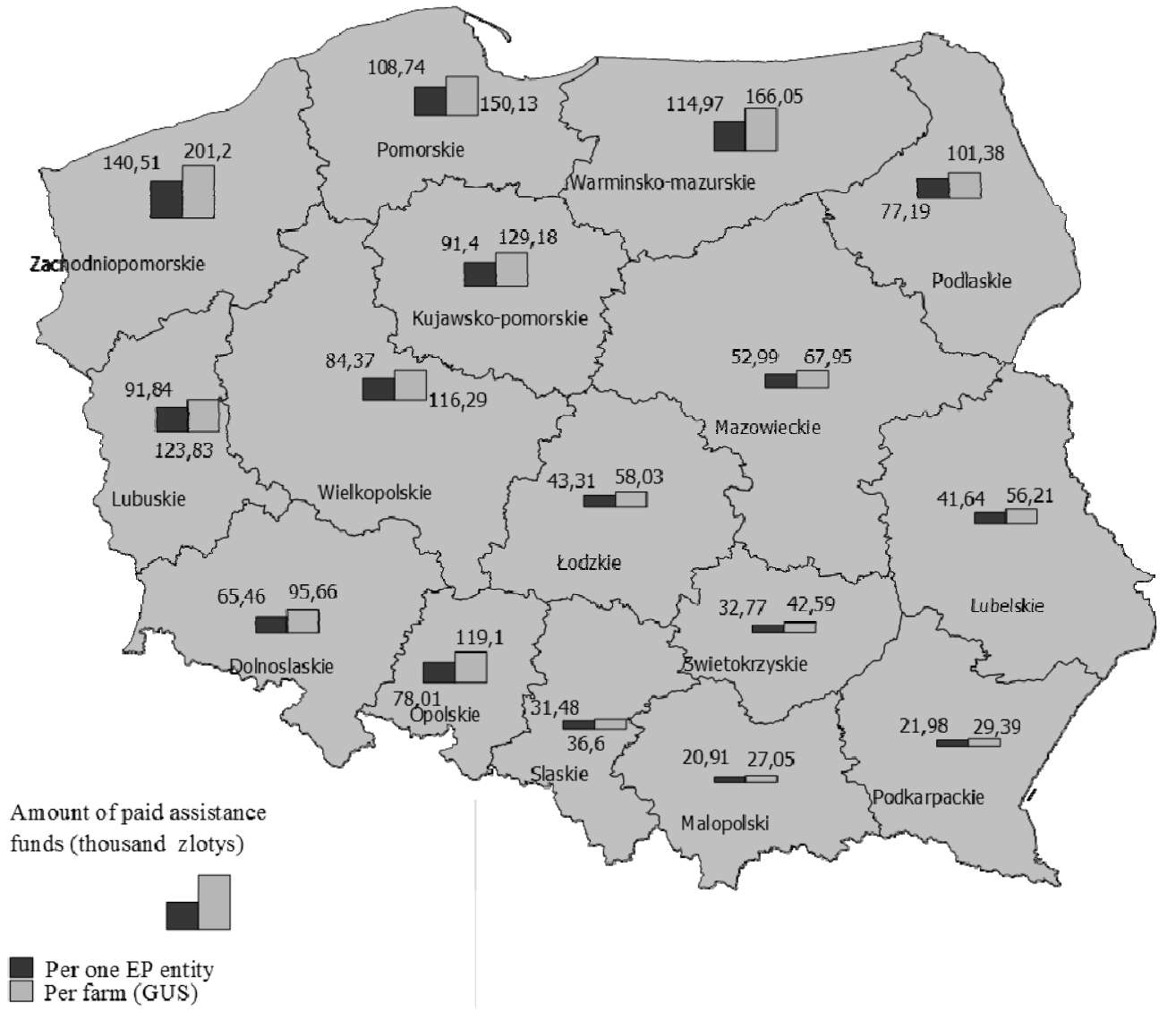

Source: statistical elaboration by ARMA 2012 (ARiMR, 2012) 


\section{Conclusions}

Due to natural, historical and cultural conditions, agriculture both in Poland and in the European Union countries is highly diversified both in its agrarian structure, directions of production, its intensity and the level of generated incomes.

The diversity of the European funds absorption in Poland results from the size of agricultural sector. Analysis of utilization of the assistance granted since the beginning of implementation of the programmes co-financed from the EU funds until 31.12.2011 as per regions, revealed that the highest amount of payments was realized for the following voivodships: Mazowieckie, Wielkopolskie, Lubelskie - where the highest number of large area farms is operating.

Efficient utilization of the EU funds for investment purposes is not favourable for the regions with dispersed agrarian structure, small area farms and greatly dispersed lands owned by individual farms.

In "big" voivodships farmers have a better access to agricultural extension specialists and professional help in the area of European funds.

Farmers reveal a great interest and efficiency in the EU funds acquisition.

The structure of expenditure of agricultural farms looks positive and rational (almost $60 \%$ is expenditure on investment in farm). All EU grants affected not only increase in farm income, but primarily the level of investment in farms.

Increasingly higher funds end up on Polish farms and farmers are no longer afraid to use the EU assistance.

Poland's accession to the European Union opened a new chapter in rural development. Capital mainly targeting the agriculture and rural development reached Polish country.

CAP has its values resulting from the community character, but has to allow for such high diversification of agriculture as observed e.g. in Poland. It requires application of various support instruments. It cannot be conveyed only to equalizing the level of support, but it is necessary to use the instruments characteristic not so for the countries as for the regions. Sometimes a local or even individual approach will prove necessary. For solving the problems of small farms, not only the policy connected with the CAP $2^{\text {nd }}$ pillar should be important, but also the EU cohesion policy, therefore the participation of local governments is crucial.

\section{References}

1. Czapla J., Guba W. Wspólna (2002): Polityka Rolna i jej skutki dla Polski po akcesji do Unii Europejskiej 2002. Sekcja Analiz Ekonomicznych Polityki Rolnej, Fundacja Programów Pomocy dla Rolnictwa, Warszawa

2. Drygas M., (2008): Polska wieś i rolnictwo w Unii Europejskiej. Dylematy i kierunki przemian, IRiRW pod. red. Naukową Mirosława Drygasa i Andrzeja Rosnera, Warszawa

3. Klepacki B. (2003): Organizacyjno - ekonomiczne uwarunkowania wykorzystania potencjału polskiego rolnictwa, Pamiętnik Puławski. Z.132; Warszawa 
Kornalska, E. - Krasnodębski, A. - Żmija, J. - Trela, W.

4. Kornalska E., Trela W., (2012): Episteme 15/2012 [in:] Ocena możliwości finansowania procesów modernizacyjnych w gospodarstwach rolnych województwa świętokrzyskiego, Kraków

5. Musiał W., Legutko S. (2000): Wybrane aspekty kształtowania polityki rolnej państwa Unii Europejskiej [w:] Wybrane problemy integracji wsi i rolnictwa Polski z Unią Europejską, Małopolskie Stowarzyszenie Doradztwa Rolniczego, Kraków

6. Rowiński J. (2004): Wspólna Polityka Rolna [in:] E. Kawecka-Wyrzykowska [red.] Unia Europejska, Wydaw. Instytut Koniunktur i Cen Handlu Zagranicznego, Warszawa

7. Szumski A. (2007): „Wspólna Polityka Rolna Unii Europejskiej”, Wydawnictwa Akademickie i Profesjonalne, Warszawa

8. Zegar J. (2012): Problemy drobnych gospodarstw rolnych 1-2012, Kraków

9. Zieliński K., Żmija D. (2012): Instrumenty polityki rolnej Unii Europejskiej stosowane w Polsce, Wyd. Uniwersytetu Ekonomicznego w Krakowie, Kraków

10. Charakterystyka gospodarstw rolnych (2012): Powszechny Spis Rolny 2010. Główny Urząd Statystyczny, Warszawa

11. Dokument rządowy PROW 2007-2013, Materiały informacyjne ARiMR w Warszawie

12. Report Agribus 2012 Agencji Martin \& Jacob

13. SAEPR FAPA na podstawie EUROSTAT, Eurostat 2011

14. Materiały informacyjne ARiMR 2012 